\title{
Acute inflammation and hematological response in Nile tilapia fed supplemented diet with natural extracts of propolis and Aloe barbadensis
}

\author{
Dotta, G. ${ }^{a}$, Ledic-Neto, J. ${ }^{a}$, Gonçalves, ELT. ${ }^{a}$,Brum, A. ${ }^{a}$, Maraschin, M. ${ }^{b}$ and Martins, ML. ${ }^{a *}$ \\ aLaboratório de Sanidade de Organismos Aquáticos - AQUOS, Departamento de Aqüicultura, Centro de Ciências Agrárias, \\ Universidade Federal de Santa Catarina - UFSC, Rod. Admar Gonzaga, 1346, CEP 88040-900, Florianópolis, SC, Brazil \\ ${ }^{b}$ Laboratório de Morfogênese e Bioquímica Vegetal, Departamento de Fitotecnia, Universidade Federal de \\ Santa Catarina - UFSC, Rod. Admar Gonzaga, 1346, CEP 88040-900, Bloco B, Florianópolis, SC, Brazil \\ *e-mail: mauricio.martins@ufsc.br
}

Received: February 7, 2014 - Accepted: April 17, 2014 - Distributed: May 31, 2015

(With 2 Figures)

\begin{abstract}
This study evaluated the acute inflammatory response induced by carrageenin in the swim bladder of Nile tilapia supplemented with the mixture of natural extracts of propolis and Aloe barbadensis (1:1) at a concentration of $0.5 \%, 1 \%$ and $2 \%$ in diet during 15 days. Thirty-six fish were distributed into four treatments with three replicates: fish supplemented with $0.5 \%$ of admix of extracts of propolis and Aloe (1:1) injected with $500 \mu \mathrm{g}$ carrageenin; fish supplemented with $1 \%$ of admix of extracts of propolis and Aloe (1:1) injected with $500 \mu \mathrm{g}$ carrageenin; fish supplemented with $2 \%$ of admix of extracts of propolis and Aloe (1:1), injected with $500 \mu \mathrm{g}$ carrageenin and unsupplemented fish injected with $500 \mu \mathrm{g}$ carrageenin. Six hours after injection, samples of blood and exudate from the swim bladder of fish were collected. It was observed an increase in the leukocyte count in the swim bladder exudate of fish supplemented with extracts of propolis and Aloe injected with carrageenin. The most frequent cells were macrophages followed by granular leukocytes, thrombocytes and lymphocytes. Supplementation with propolis and Aloe to $0.5 \%$ caused a significant increase in the number of cells on the inflammatory focus mainly macrophages, cells responsible for the phagocytic activity in tissues, agent of innate fish immune response.
\end{abstract}

Keywords: inflammation, carrageenin, swim bladder, propolis, Aloe.

\section{Inflamação aguda e resposta hematológica em tilápias do Nilo alimentadas com extratos naturais de própolis e Aloe barbadensis suplementados na dieta}

\section{Resumo}

Este estudo avaliou a resposta inflamatória aguda induzida por carragenina na bexiga natatóriade tilápia do Nilo suplementada com a mistura dos extratos naturais de própolis e Aloe barbadensis (1:1), nas concentrações de $0,5 \%$, $1 \%$ e $2 \%$ na dieta durante o período de 15 dias. Trinta e seis peixes foram distribuídos em quatro tratamentos com três repetições: peixes suplementados com $0,5 \%$ da mistura dos extratos de própolis e Aloe (1:1) injetados na bexiga natatória com $500 \mu \mathrm{g}$ de carragenina; peixes suplementados com $1 \%$ da mistura dos extratos de própolis e Aloe (1:1) injetados na bexiga natatória com $500 \mu \mathrm{g}$ de carragenina; peixes suplementados com $2 \%$ da mistura dos extratos de própolis e Aloe (1:1) injetados na bexiga natatória com $500 \mu \mathrm{g}$ de carragenina e peixes não suplementados injetados na bexiga natatória com $500 \mu \mathrm{g}$ de carragenina. Seis horas após as injeções foram coletadas amostras de sangue e exsudato da bexiga natatória dos peixes. Foi observado aumento na contagem de leucócitos no exsudato da bexiga natatória de peixes suplementados com os extratos de própolis e Aloe injetados com carragenina. As células mais frequentes foram os macrófagos seguidos pelos leucócitos granulares, trombócitos e linfócitos. A suplementação com própolis e Aloe a $0,5 \%$ provocou aumento significativo no número de células no foco inflamatório, principalmente dos macrófagos, células responsáveis pela atividade fagocitária nos tecidos, agente da resposta imune inata nos peixes.

Palavras-chave: inflamação, carragenina, bexiga natatória, própolis, Aloe.

\section{Introduction}

Inflammation is one of the major host defenses against all forms of aggression. By definition, according to Thomson (1983), inflammation is the vascular response of living tissues and cells to a certain attack, that may result in passive and chemical changes in attacked cells or tissues, which initiate the inflammatory process. In fishes, 
the inflammatory process may be inducted by biological, chemical or physical agents (Kumar et al., 2004).

The role of the inflammatory process is to minimize irritating effects on injured tissues, and the primary response to injury is an accumulation of fluids and cells in the injured area for mobilization of immune cells such as leukocytes, macrophages and lymphocytes to the inflamed site. The rapid migration of leucocytes from microcirculation to inflammatory site is the most important characteristic of this process (Garcia-Leme, 1989). The set of fluids and cells is called exudate, and its purpose is to dilute, find, destroy and remove the irritant, leading to replacement of injured tissue portions.

The exudate is a mean for recognition of inflammatory process in tissues. In fish, the assessment of inflammatory response depends on three major factors: first is the difficulty of identification of leukocytes, that depends on the species, the second is related to ontogenetic variation in blood and inflammatory cells (Tavares-Dias and Moraes, 2004), and third kinetics of inflammatory process, which may be influenced by dietary supplementation (Moraes et al., 2003; Belo et al., 2005, 2012; Dotta et al., 2011), by the kind of inflammatory stimulous (Bozzo et al., 2007), by eicosanoids (Claudiano, 2011), by the ambiental temperature (Dias and Sinhorini, 1991; Jansson Junior and Waaler, 1967) and by circulating hormones (Martins et al., 2000; Belo et al., 2005, 2012).

Cellular response can be evaluated by inducing an inflammatory process such as injections of carrageenin, sulphated polysaccharide, classically used in the acute inflammation assays. In fish, carrageenin, thioglycolate and inactivated Aeromonas hydrophila were tested in the swim bladder of Piaractus mesopotamicus (Martins et al., 2000; Moraes et al., 2003; Bozzo et al., 2007) and Oreochromis niloticus (Martins et al., 2004; Dotta et al., 2011). According to Bozzo et al. (2007), thioglycolate and inactivated Aeromonas hydrophila induced vascular congestion, accumulation of thrombocytes followed by macrophages, granulocytes and oedema. The choice of swim bladder as local for assessment of inflammatory response is based on studies of Van Furth (1992), which showed that body cavities are an experimental model to represent the mechanisms of inflammatory response that can occur in the other animal tissues.

An efficient method to control diseases in aquaculture is strengthened fish defense mechanism by prophylactic administration of immunestimulants (Drago et al., 2000). Besides, alternatives for the use of chemicals are needed to prevent and avoid infections (Romano and Mejía, 2003). On this view, natural products must be tested to minimize the environmental degradation by indiscriminate use of chemicals.

The hypotesis of this assay was to verify whether supplemented diet with natural extracts of propolis and babosa Aloe barbadensis Miller may influence the acute inflammation and hematological response when carrageenin is injected in the swim bladder of Nile tilapia, a proved experimental model.

\section{Material and Methods}

\subsection{Experimental conditions}

Thirty-six juveniles Nile tilapia $(22.3 \pm 12.7 \mathrm{~g}$ mean weight and $12.4 \pm 2.7 \mathrm{~cm}$ total lenght) from the same spawning were stored into polyethylene water tanks with a capacity of $100 \mathrm{~L}$, provided with a biological filter, heater and constant aeration, maintained under the following conditions: temperature $24.0 \pm 2.8^{\circ} \mathrm{C}$ and dissolved oxygen $6.0 \pm 0.0 \mathrm{mg} / \mathrm{L}$ (Hanna, HI 9146), $\mathrm{pH} 6.51 \pm 0.43$ (Alfakit, AT-350) and ammonia $0.09 \pm 0.33 \mathrm{mg} / \mathrm{L}$ (Alfakit, colorimetric method). After seven days of acclimation, feeding with the experimental diets was started and continued for 15 days, to perform induction of inflammatory response to injection of $500 \mu \mathrm{g}$ carrageenin (Marine Colloids) diluted in $0.5 \mathrm{ml}$ saline solution. Fish were distributed in a completely randomizated factorial design divided in four treatments with three replicates: fish supplemented with $0.5 \%$ of admix of extracts of propolis and Aloe (1:1) injected with $500 \mu \mathrm{g}$ carrageenin; fish supplemented with $1 \%$ of admix of extracts of propolis and Aloe (1:1) injected with $500 \mu \mathrm{g}$ carrageenin; fish supplemented with $2 \%$ of admix of extracts of propolis and Aloe (1:1), injected with $500 \mu \mathrm{g}$ carrageenin and unsupplemented fish injected with $500 \mu \mathrm{g}$ carrageenin.

\subsection{Supplemented diet preparation}

After fish biomass calculation fish were fed at $3 \%$ body weight with commercial diet supplemented or not with natural extracts. Propolis and $A$. barbadensis were added to the ration in the amounts of $1: 1$ to get a final concentration of $0.5 ; 1$ and $2 \%$ of the total quantity of offered food per day. The extracts of propolis and babosa were diluted in 50\% alcohol before diet mixture.

\subsection{Injection and collection of exudate cells}

After feeding period of 15 days, fish were anesthetized with clove oil at a concentration of $100 \mathrm{mg} . \mathrm{L}^{-1}$ to be injected with carrageenin in the swim bladder, according to Dotta et al. (2011). Six hours after injections they were euthanized with clove oil for collection of blood and swim bladder exudate cells (Ethic Committee $\mathrm{n}^{\circ}$ 23080.009240/2011-93/CEUA/UFSC). After opening the abdominal cavity, the swim bladder was ruptured and washed with $0.5 \mathrm{ml}$ of phosphate buffer solution (PBS) with a drop of $0.001 \mathrm{ml}$ of 5\% EDTA. Briefly, with the aid of pipete the content was collected, maintained in ice for total leucocyte count. Afterthat, the exudate was centrifuged at $150 \mathrm{G}$ for $10 \mathrm{~min}$, the supernatant discharged to use the pellet for smears that were stained with Giemsa for $10 \mathrm{~min}$ according to Dotta et al. (2011) to determine differential cell count. 


\subsection{Hematological parameters}

Blood samples were collected from the caudal vein using a syringe containing a drop of $10 \%$ EDTA solution (Ethic Committee n ${ }^{\circ}$ 23080.009240/2011-93/CEUA/UFSC) to measure hematocrit (Goldenfarb et al., 1971), red blood cells count in a Neubauer chamber, total counts of leukocytes and thrombocytes and differential count of leukocytes. Blood smears in duplicate were stained with a lood combination of Giemsa/May-Grünwald (Rosenfeld, 1947). The smears were used for differential leukocyte count and the total count of thrombocytes and leukocytes (Martins et al., 2004).

\subsection{Statistical analysis}

Data was submited to factorial analysis of variance (ANOVA) using Statsoft. Bartlett test was used to verify the homoscedasticity while Tukey test was used to compare means. Data transformations were used according to pertinence.

\section{Results}

Hematological parameters as hematocrit and number of red blood cells did not show significant difference $(\mathrm{P}>0.05)$ among the treatments (Table1). In the circulating blood, there was a reduction in the number of total leukocytes in fish fed $1 \%$ and $2 \%$ of the mixtures of extracts. On the other hand, fish fed $0.5 \%$ and unsupplemented fish did not differ in the number of total leukocyes (Table 1). The differential leukocyte count in circulating blood (Figure 1) showed changes between treatments. The inflammatory response evaluated from the swim bladder exudate (Table 1) revealed a significant increase in total leukocyte count in fish supplemented with $0.5 \%$ extract mixture in the diet, compared to the other treatments, especially in relation to non-supplemented animals.

In differential count of exudate cells, lymphocytes were the most abundant cells, followed by thrombocytes, granulocytes and macrophages (Figures 1 and 2).

Table 1. Mean values and standard deviation of hematological parameters in circulating blood and total leukocytes count in swim bladder exudate of Oreochromis niloticus fed supplemented diet with propolis and Aloe (1:1) in different concentrations.

\begin{tabular}{ccccc}
\hline & & Circulating blood & Exudate \\
\hline Treatments & Hematocrit $(\%)$ & $\begin{array}{c}\text { Erythrocytes } \\
\left(\mathbf{x} \mathbf{1 0}^{6} \cdot \boldsymbol{\mu} \mathbf{L}^{-1}\right)\end{array}$ & $\begin{array}{c}\text { Total leukocytes } \\
\left(\mathbf{x 1 0}^{3} \cdot \boldsymbol{\mu L} \mathbf{L}^{-1}\right)\end{array}$ & $\begin{array}{c}\text { Total leukocytes } \\
\left(\mathbf{x} \mathbf{1 0}^{6} \cdot \boldsymbol{\mu} \mathbf{L}^{-1}\right)\end{array}$ \\
\hline $0.5 \%+$ IC & $20.88 \pm 7.11 \mathrm{a}$ & $2.32 \pm 0.66 \mathrm{a}$ & $34.79 \pm 17.47 \mathrm{~b}$ & $0.65 \pm 0.90 \mathrm{c}$ \\
$1 \%+$ IC & $23.0 \pm 5.32 \mathrm{a}$ & $2.41 \pm 0.26 \mathrm{a}$ & $29.47 \pm 16.59 \mathrm{a}$ & $0.23 \pm 0.48 \mathrm{~b}$ \\
$2 \%+$ IC & $23.60 \pm 5.85 \mathrm{a}$ & $2.11 \pm 0.37 \mathrm{a}$ & $30.33 \pm 10.59 \mathrm{a}$ & $0.35 \pm 0.36 \mathrm{~b}$ \\
NS + IC & $24.28 \pm 5.58 \mathrm{a}$ & $2.23 \pm 0.48 \mathrm{a}$ & $33.46 \pm 11.09 \mathrm{~b}$ & $0.08 \pm 0.01 \mathrm{a}$ \\
\hline
\end{tabular}

Lowercase letters indicate a significant difference between treatments $(\mathrm{p}<0.05)$. Injected with carrageenin (IC) and non-supplemented (NS).
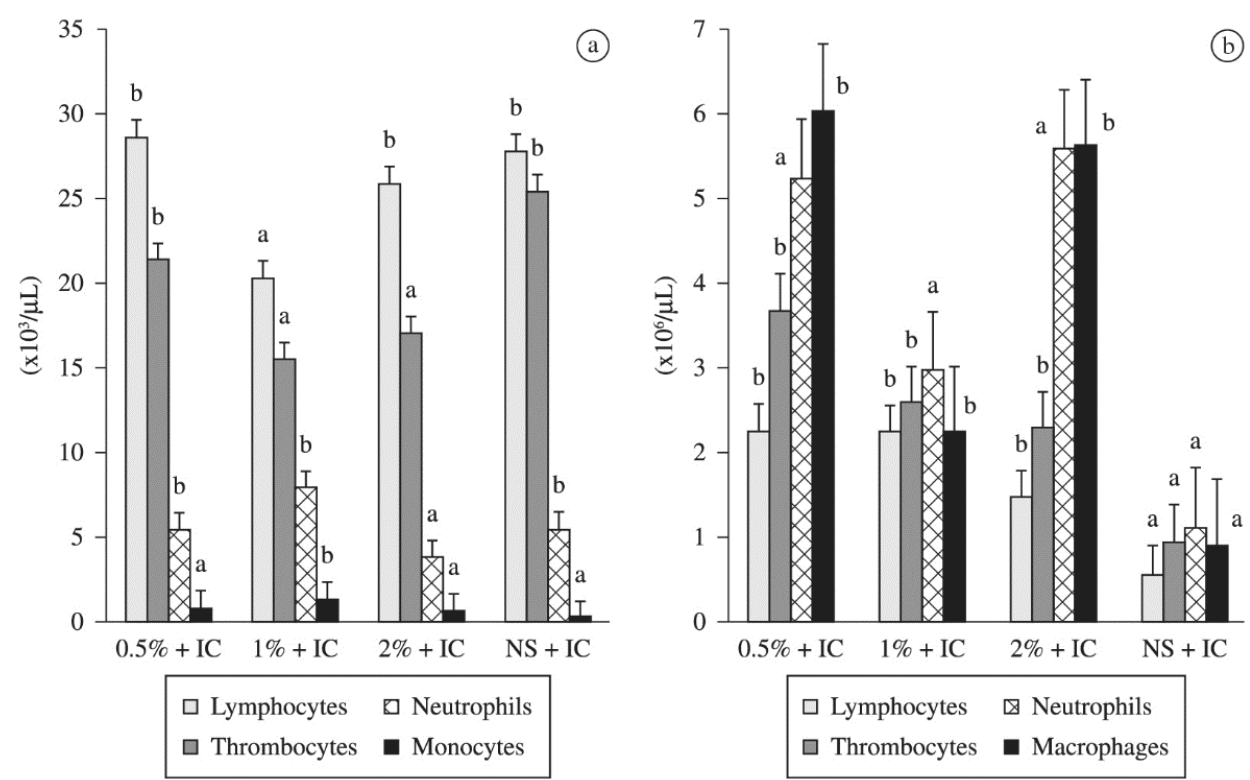

Figure 1. Mean values of total leukocyte and thrombocyte counts in circulating blood (a) and inflammatory exudate (b) of Oreochromis niloricus fed supplemented diet with propolis and Aloe (1:1) in different concentrations. Lowercase letters indicate a significant difference between treatments $(\mathrm{p}<0.05)$. Injected with carrageenin (IC) and non-supplemented (NS). 


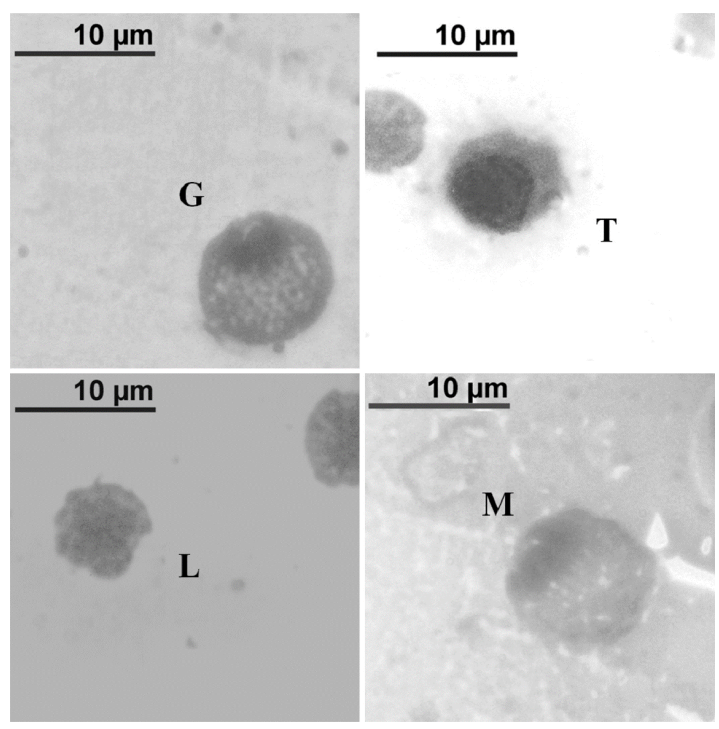

Figure 2. Exudate cells of Oreochromis niloticus fed supplemented diet with propolis and Aloe (1:1) in different concentrations. Granulocytes (G), thrombocytes (T), lymphocytes (L) and macrophages (M).

\section{Discussion}

Carrageenin injection caused accumulation of inflammatory cells into the swim bladder of Nile tilapia, as reported by Dotta et al. (2011). The circulating blood cells that migrate into tissues to participate in inflammatory response include thrombocytes, lymphocytes, macrophages and granulocytes, corroborating previous studies. (Bozzo et al., 2007; Reque et al., 2010; Salvador et al., 2012; Claudiano, 2011).

In this assay, macrophages were the most frequent cells, followed by neutrophils, thrombocytes and lymphocytes in fish supplemented with $0.5 \%$ and $2 \%$ of extracts mixture and injected with carrageenin. It should be noted that in studies of Bozzo et al. (2007) the authors utilized inactivated Aeromonas hydrophila to induce inflammation in Piaractus mesopotamicus, and the second most frequent cells were lymphocytes. This may be related to the kind of irritant agent, the bacterium. Martins et al. (2009) observed that tilapia injected with $1 \times 10^{6}$ colony forming units Enterococcus $/ \mathrm{ml}$ showed higher number of thrombocytes. Thrombocytes are important cells of hemostasis also involved in the organic defense as reported in previous studies (Ellis et al., 1976; Penha et al., 1996; Matushima and Mariano, 1996; Martins, et al., 2000). studies (Ellis et al., 1976; Penha et al., 1996; Matushima and Mariano, 1996; Martins, et al., 2000). The importance of thrombocytes as a phogocytic-cell has been reported in birds, Gallus gallus domesticus (Grecchi et al., 1980; Kajigaya et al., 1985), bullfrog, Lithobathes catesbeianus (Ishida et al., 1985; Dias and Sinhorini, 1991; Penha et al., 1996) and tilapia (Suzuki, 1986; Matushima and Mariano, 1996). Similarly to the present results, Reque et al. (2010) observed increased number of thrombocytes accompanied by lowered number of macrophages, neutrophils and lymphocytes in the inflammatory exudates of tilapia fed Saccharomyces cerevisae.

Zanuzzo (2010) evaluated the respiratory burst of macrophages in Brycon amazonicus, kept in water containing $A$. vera, and observed an increase in the respiratory activity of leucocytes. These findings indicate that $A$. vera can be reacted with the neutrophil membrane receptors by stimulating the ROS (reactive oxygen species) production. According to Jorgensen and Robertsen (1995), an increase in the ROS production could be considered as indicator of non-specific immune system activation. Zhang et al. (2009), observed significant increase in the respiratory burst, phagocytosis and lyzozyme activity in $O$. niloticus when fed propolis extracts The presence of a great number of phagocytic cells found in this assay suggests that this fish supplemented with the extracts of propolis and babosa showed increased acute inflammation. "In vitro" tests with inflammatory cells from circulating blood are needed, such as conducted by Zhang et al. (2009) and Zanuzzo (2010) to evaluate the phagocytic activity of these cells.

In agreement with the findings of Reque et al. (2010) in tilapia fed supplemented diet with Saccaromyces cerevisiae, the acute inflammation induced by $A$. hydrophila did not show alterations in hematocrit.

Hematological parameters assessments may be important indicators of fish health status (Martins et al., 2008). Similarly, Cuesta et al. (2005) have related increased number of monocyte-macrophages and granulocytes phagocytosis from the blood of Sparus aurata fed supplemented diet with propolis. On the other hand, a gradated increase in leucocyte accumulation on the inflammatory site induced by Escherichia coli injection was reported for tilapia with the highest migration activity 24 hours after injection (Matsuyama and Iida, 1999).

The use of vegetal extracts on fish food has been responsible for enhancement of the immune system not only in the specific response but also in the non-specific as shown in Catla catla fed diet supplemented with Achyranthes aspera (Rao Y and Chakrabarti, 2005).

To state precisely the real effectiveness of immunestimulants supplementation in fish, careful analysis is needed (Zhang et al., 2009). With the evaluation of inflammatory response in the swim bladder of tilapia, there was a significant increase in cell accumulation to the site of injection of carrageenin, and increased number of macrophages in fish supplemented with $0.5 \%$ of propolis and Aloe extracts mixture.

In addition, studies must be encouraged to analysis the feasibility of the use of natural extracts in fish farm to minimize the economic losses caused by infectious or parasitic diseases. 


\section{References}

BELO, MAA., MORAES, JRE., SOARES, VE., MARTINS, ML., BRUM, CD. and MORAES, FR., 2012. Vitamin C and endogenous cortisol in foreignbody inflammatory response in pacus. Pesquisa Agropecuária Brasileira, vol. 47, no. 7, p. 1015-1021,

BELO, MAA., SCHALCH, SHC., MORAES, FR., SOARES, VE., OTOBONI, AMMB. and MORAES, JER., 2005. Effect of dietary supplementation with vitamin $\mathrm{E}$ and stocking density on macrophage recruitment and giant cell formation in the teleost fish, Piaractus mesopotamicus. Journal of Comparative Pathology, vol. 133, no. 2-3, p. 146-154. http://dx.doi.org/10.1016/j. jcpa.2005.04.004. PMid:16033696

BOZZO, FR., MORAES, JRE., MORAES, FR., PEREIRA, GT., TAVARES-DIAS, M. and ONAKA, EM., 2007. Kinetics of cellular component in inflammatory response induced by different stimuli in the swim bladder of Piaractus mesopotamicus, Holmberg, 1887 (Characidae). Journal of the World Aquaculture Society, vol. 38, no. 2, p. 302-308. http://dx.doi.org/10.1111/j.17497345.2007.00100.x.

CLAUDIANO, GS., 2011. Eicosanoides no aumento de permeabilidade vascular e componente celular da inflamação aguda em Piaractus mesopotamicus. Jaboticabal: Faculdade de Ciências Agrárias e Veterinárias, Universidade Estadual de São Paulo. Doctoral thesis in Animal Pathology.

CUESTA, A., RODRÍGUEZ, A., ESTEBAN, MA. and MESEGUER, J., 2005. In vivo effects of propolis, a honeybee product, on gilthead seabream innate immune responses. Fish \& Shellfish Immunology, vol. 18, no. 1, p. 71-80. http://dx.doi.org/10.1016/j. fsi.2004.06.002. PMid:15450970

DIAS, JLC. and SINHORINI, IL., 1991. Qualitative evaluation of the inflammatory response modulated by temperature in tadpoles of Rana catesbeiana. Ciencia e Cultura, vol. 43, no. 4, p. 304-306.

DOTTA, G., MOURIÑO, JLP., JERÔNIMO, GT., JATOBÁ, AMB., MORÁN, REB. and MARTINS, ML., 2011. Acute inflammatory response in Nile tilapia fed probiotic Lactobacillus plantarum in the diet. Acta Scientiarum, vol. 33, no. 3, p. 239-246.

DRAGO, L., MOMBELLI, B., VECCHI, E., FASSINA, MC., TOCALLI, L. and GISMONDO, MR., 2000. In vitro antimicrobial activity of propolis dry extract. Journal of Chemotherapy, vol. 12, no. 5, p. 390-395. http://dx.doi.org/10.1179/joc.2000.12.5.390. PMid:11128558

ELLIS, AE., MUNROE, ALS. and ROBERTS, RJ., 1976. Defence mechanisms in fish. 1. A study of the phagocytic system and the fate of intraperitoneally injected particulate material in the plaice (Pleuronectes platessa L.). Journal of Fish Biology, vol. 8, no. 1. p. 67-78. http://dx.doi.org/10.1111/j.1095-8649.1976.tb03908.x.

GARCIA-LEME, J., 1989. Hormones and Inflammation. Boca Raton: CRC Press.

GOLDENFARB, PB., BOWYER, FP., HALL, E. and BROSIOUS, E., 1971. Reproducibility in the hematology laboratory: the microhematocrit determination. American Journal of Clinical Pathology, vol. 56, no. 1, p. 35-39. PMid:5556212.

GRECCHI, R., SALIBA, AM. and MARIANO, M., 1980. Morphological changes, surface receptors and phagocytic potential of fowl mono-nuclear phagocytes and thrombocytes in vivo and in vitro. The Journal of Pathology, vol. 130, no. 1, p. 23-31. http:// dx.doi.org/10.1002/path.1711300104. PMid:7381624
ISHIDA, Y., SUGYIAMA, M., KAJIGAYA, H., UMEDEA, M. and ISODA, M., 1985. Inflammatory reactions on Japanese quails muscular tissue caused by sutures. Bulletin Nippon Veterinary Zootechny College., vol. 31, p. 39-46.

JANSSON JUNIOR, CW. and WAALER, E., 1967. Body temperature, antibody formation and inflammatory response. Acta Pathologica et Microbiologica, vol. 69, no. 4, p. 566-577.

JØRGENSEN, JB. and ROBERTSEN, B., 1995. Yeast betaglucan stimulates respiratory burst activity of Atlantic salmon (Salmo salar L.) macrophages. Developmental and Comparative Immunology, vol. 19, no. 1, p. 43-57. http://dx.doi.org/10.1016/0145305X(94)00045-H. PMid:7615137

KAJIGAYA, H., KAMEKURA, M., TANAHARA, N., OTHA, A., SUZUKI, H., SUGIYAMA, M. and ISODA, M., 1985. Acute and chronic inflammation induced by silk sutures in chicken mesentery. Bull. Nippon Veterinary Zootechny College, vol. 34, p. 35-38.

KUMAR, V., ABBAS, A. and FAUSTO, N., 2004. Robbins and Cotran: pathologic basis of diseases. 7th ed. Philadelphia: Saunders. $1552 \mathrm{p}$.

MARTINS, ML., MORAES, FR., MORAES, JRE. and MALHEIROS, EB., 2000. Falha na resposta do cortisol ao estresse por captura e por carragenina em Piaractus mesopotamicus Holmberg, 1887 (Osteichtheyes: Characidae). Acta Scientiarum, vol. 22, no. 2, p. $545-552$.

MARTINS, ML., MOURIÑO, JL., AMARAL, GV., VIEIRA, FN., DOTTA, G., JATOBÁ, AM., PEDROTTI, FS., JERÔNIMO, GT., BUGLIONE-NETO, CC. and PEREIRA-JUNIOR, G., 2008. Haematological changes in Nile tilapia experimentally infected with Enterococcus sp. Brazilian Journal of Biology $=$ Revista Brasileira de Biologia, vol. 68, no. 3, p. 657-661. http://dx.doi. org/10.1590/S1519-69842008000300025. PMid:18833489

MARTINS, ML., PILARSKY, F., ONAKA, EM., NOMURA, DT., FENERICK-JÚNIOR, J., RIBEIRO, K, MIYAZAKI, DMY., CASTRO, MP., MALHEIROS, EB., 2004. Haematology and acute inflammatory response of Oreochromis niloticus (Osteichthyes: Cichlidae) submitted to a single and consecutive stress of capture. Boletim do Instituto de Pesca, vol. 30, no. 1, p. 71-80.

MARTINS, ML., VIEIRA, FN., JERÔNIMO, GT., MOURIÑO, JLP., DOTTA, G., SPECK, GM., BEZERRA, AJM., PEDROTTI, FS., BUGLIONE-NETO, CC. and PEREIRA, G Jr., 2009. Leukocyte response and phagocytic activity in Nile tilapia experimentally infected with Enterococcus sp. Fish Physiology and Biochemistry, vol. 35, no. 1, p. 219-222. http://dx.doi.org/10.1007/s10695-0089262-x. PMid:18777139

MATSUYAMA, T. and IIDA, T., 1999. Degranulation of eosinophilic granular cells with possible involvement in neutrophil migration to site of inflammation in tilapia. Developmental and Comparative Immunology, vol. 23, no. 6, p. 451-457. http://dx.doi.org/10.1016/ S0145-305X(99)00027-0. PMid:10512456

MATUSHIMA, ER. and MARIANO, M., 1996. Kinetics of the inflammatory reaction induced by carrageenin in the swim bladder of Oreochromis niloticus (Nile tilapia). Brazilian Journal of Veterinary Research and Animal Science, vol. 33, p. 5-10.

MORAES, JR., FREITAS, J., BOZZO, FR., MORAES, FR. and MARTINS, ML., 2003. A suplementação alimentar com vitamina $\mathrm{C}$ acelera a evolução do processo cicatricial em Piaractus mesopotamicus (Holmberg, 1887). Boletim do Instituto de Pesca, vol. 29 , p. 57-67. 
PENHA, ML., DIAS, JLC. and MALUCELLI, BE., 1996. Influence of low environmental temperature on the phagocytic activity of bullfrog (Rana catesbeiana) thrombocytes. Brazilian Journal of Veterinary Research and Animal Science, vol. 33, no. 1, p. 15-18.

RAOY, V. and CHAKRABARTI, R., 2005. Stimulation of immunity in Indian major carp Catla catla with herbal feed ingredients. Fish \& Shellfish Immunology, vol. 18, no. 4, p. 327-334. http://dx.doi. org/10.1016/j.fsi.2004.08.005. PMid:15561562

REQUE, VR., MORAES, JRE., BELO, MAA. and MORAES, FR., 2010. Inflammation induced by Aeromonas hydrophila in Nile tilapia fed diets supplemented with Saccharomyces cerevisiae. Aquaculture (Amsterdam, Netherlands), vol. 300, no. 1-4, p. 37-42. http://dx.doi.org/10.1016/j.aquaculture.2009.12.014.

ROMANO, LA. and MEJIA, J., 2003. Infección por Streptococcus iniae: Una enfermedad emergente que afecta a peces de cultivo y a humanos. Revista Aquatic, vol. 18, p. 25-32.

ROSENFELD, G., 1947. Corante pancrômico para hematologia e citologia clínica. Nova combinação dos componentes do May-Grunwald e do Giemsa num só corante de emprego rápido. Memorias do Instituto Butantan, vol. 20, p. 329-335.

SALVADOR, R., TOAZZA, CS., MORAES, JR. and MORAES, FR., 2012. Inflammatory responses of Nile tilapia Oreochromis niloticus to Streptococcus agalactiae: effects of vaccination and yeast diet supplement. Diseases of Aquatic Organisms, vol. 98, no. 3, p. 235-241. http://dx.doi.org/10.3354/dao02438. PMid:22535873
SUZUKI, K., 1986. Morphological and phagocytic characteristics of peritoneal exudate cells in tilapia, Oreochromis niloticus (Trewavas), and carp, Cyprinus carpio L. Journal of Fish Biology, vol. 29, no. 3, p. 349-364. http://dx.doi.org/10.1111/j.1095-8649.1986. tb04951.x.

TAVARES-DIAS, M. and MORAES, FR., 2004. Hematologia de peixes teleósteos. Ribeirão Preto: Villimpress.

THOMSON, RG., 1983. General and veterinary pathology. Philadelphia: W. B. Saunders.

VAN-FURTH, R., 1992. Development and distribution of mononuclear phagocytes in normal steady state and inflammation. In GALLIN, JI., GOLDSTEIN, IM., SNYDERMAN, R. Inflammation: basic principles and clinical correlates. 2nd ed. New York: Raven Press. p. 325-333.

ZANUZZO, FS., 2010. Uso da Aloe vera L. no manejo de matrinxã (Brycon amazonicus). Jaboticabal: Faculdade de Ciências Agrárias e Veterinárias, Universidade Estadual de São Paulo. 86 p. Masters Dissertation in Aquiculture.

ZHANG, G., GONG, S., YU, D. and YUAN, H., 2009. Propolis and Herba Epimedii extracts enhance the non-specific immune response and disease resistance of Chinese sucker, Myxocyprinus asiaticus. Fish \& Shellfish Immunology, vol. 26, no. 3, p. 467472. http://dx.doi.org/10.1016/j.fsi.2009.01.011. PMid:19185611 